\title{
Primary Cultures of Drosophila melanogaster Gut Cells for Studies of Intestinal Stem Cell Regulation
}

\author{
Young-\|l Yoon ${ }^{1}$, Jae-Sam Hwang ${ }^{1}$, Tae-Won Goo', Myung-Sae Han², Mi-Young Ahn ${ }^{1}$ and Eun-Young Yun ${ }^{1}$ * \\ ${ }^{1}$ Department of Agricultural Biology, National Academy of Agricultural Science, RDA, Suwon 441-100, Korea \\ ${ }^{2}$ Department of Bio-Fibers and Materials Science, Kyungpook National University, Daegu 702-701, Korea
}

Received February 14, 2012 /Revised May 4, 2012 /Accepted May 7, 2012

\begin{abstract}
Drosophila melanogaster has been used as a useful model to study development and disease. In this study, we established the primary culture method of Drosophila in the intestine to understand how intestinal stem cells (ISCs) mediate tissue repair during infection and disease. To obtain intestinal cells, we separated intestines from adult flies and isolated single cells by enzymatic treatment. The survival of cultured cells was measured using MTS-analysis. The maximum growth rate of the cells was observed on the 9th day after seeding. In addition, the presence of ISCs and enteroendocrine cells was confirmed by delta and prospero staining. Accordingly, we supposed that Drosophila melanogaster gut cells established in this study are probably useful in studies about intestinal stem cell regulation and various diseases occurring in the intestine.
\end{abstract}

Key words : Drosophila melanogaster, primary culture, intestinal stem cells (ISCs)

\section{서 론}

염증성 장질환(inflammatory bowel disease, IBD)은 장에 발생하는 만성적인 염증질환으로 궤양성 대장염(ulcerative colitis, UC)과 크론병(Crohn's disease, $\mathrm{CD}$ )이 염증성 장질환 에 속하는 주요 질환이며, 다른 만성적인 염증질환이나 자가 면역질환과 유사하게 $\mathrm{IBD}$ 도 환경, 면역 및 유전적 요인 등의 복합적 원인에 의해 발병할 것으로 추측하나 현재까지 그 원 인과 치료법이 명확히 구명되지 않았다[11,21]. 과거에 염증성 장질환 연구는 주로 포유동물의 장세포주나 장질환을 유발한 마우스를 모델로 많은 연구가 이루어졌으나[19,26], 최근 초파 리를 모델로 이용한 성체 장줄기세포를 대상으로 한 염증성 장질환 연구가 활발히 이루어 지고 있다[1,2,18].

초파리 생체를 이용한 in vivo 실험의 경우 보다 실제 상황 과 유사하다는 장점이 있는 반면, 후보 유전자로부터 발현한 재조합 단백질의 기능 검증을 위해 초파리에 경구투여를 할 경우 목적지인 장에 도달하기 전에 다양한 단백질 분해효소 등의 공격으로 인해 재조합 단백질이 변성이나 활성을 잃을 수도 있고, 장 해부 등 번거로운 과정을 거쳐야 한다는 단점이 있다. 현재까지 곤충 유래의 세포주는 거염벌레(fall armyworm, Spodoptera frugiperda) 번데기 난소 유래의 Sf9와 Sf21 [14,23], 양배추 은무늬 밤나방(cabbage looper, Trichoplusia ni) 난소 유래의 High-Five [5,8,24,25], 누에(silkworm, Bombyx mort) 난소 유래의 Bm5 [7], 초파리(fruit fly, Drosophila mela-

*Corresponding author Tel : +82-31-290-8576, Fax : +82-31-290-8543

E-mail : yuney@korea.kr nogaster) 배 유래의 S2 [22] 및 가문비 싹벌레(spruce budworm, Choristoneura fumiferana) 중장(midgut) 유래 CF-203 [15] 세포 등이 구축되었다. 한편, 세포의 일차 배양은 초파리 에서 뇌, 정소 및 수정란을 이용한 것과 $[12,13,20]$, 배추좀나방 (plutella xylostella)의 번데기 유래 지방세포주가 보고 되었다 [4]. 따라서 현재까지 곤충의 장에 대한 세포주는 나비목인 가 문비 싹벌레(spruce budworm, Choristoneura fumiferana) 중장 (midgut) 유래 CF-203 [15]가 보고되었고, 곤충유래 중장세포 일차 배양은 담배거세미나방(Spodoptera littoralis)과 멸강나방 (Pseudaletia unipuncta)에서 보고 되었지만[9.17], 초파리 중장 유래 일차 세포의 배양법에 대한 보고는 전무하다.

세포의 일차 배양(primary culture)은 세포주 배양(cell line culture)와는 다른 특성을 가지고 있다. 세포주 배양은 불멸화 과정으로 인해 계대만으로 세포주를 유지할 수 있다는 장점과 불멸화 과정과 반복되는 배양으로 인해 본연의 특성과 성질을 그대로 가질 수 없다는 단점을 가지고 있다. 일차 배양은 일정 기간 동안만 유지된다는 단점은 있지만 조직의 특성과 성질을 그대로 지니고 있다는 장점을 가지고 있다 $[6,16]$.

따라서 본 연구에서는 실험과정의 단순화와 염증성 장질환 에 대한 재조합 단백질의 보다 효율적인 기능분석을 위해 초 파리 장세포를 일차 배양(primary culture) 하였으며, 본 연구 에서 확립한 일차 배양 장세포는 초파리 장세포를 이용한 일 차 배양의 최초 보고이다.

\section{재료 및 방법}

초파리

초파리는 살아있는 당밀/효모의 표준배지인 효모 corn- 
meal-agar-sucrose 배지로 사육되었고, 초파리 stock은 $19^{\circ} \mathrm{C}$ 에 서 유지되었으며 모든 실험은 $25^{\circ} \mathrm{C}$ 에서 이루어졌다. 본 실험 에서는 야생형인 Canton-S (CS) 품종을 사용하였다.

\section{장세포 일차 배양}

장세포의 일차 배양을 위해 100 마리의 암컷 초파리를 5 일간 $5 \%$ sucrose만을 먹인 후 10×penicillin-streptomycin이 들어있 는 $1 \times \mathrm{PBS}$ (Sigma, USA)에 침지한 상태에서 장을 분리하고, $70 \%$ 에탄올로 5 분씩 2 회 소독한 후 $1 \times \mathrm{PBS}$ 로 3 회 세척하였다. 수술용 가위와 메스를 이용하여 조직을 잘게 썰고, homogenizer (Fisher Scientific, USA)를 이용하여 장 조직을 분쇄한 후 Pasteur pipet (Volac, England)으로 pipetting을 충분히 하 여 조직을 작은 절편으로 만들었다. 그 다음 $250 \times g$ 에서 5 분 동안 원심분리한 후 상층액을 제거하고 $25^{\circ} \mathrm{C}$ 에서 TrypsinEDTA (Promega, USA)를 10분간 처리하였다. 그리고 분쇄된 초파리 장은 $1 \mathrm{unit} / \mathrm{ml}$ 의 dispase (Gibco, USA)와 $0.5 \mathrm{ug} / \mathrm{ml}$ collagenase (Sigma, USA)가 들어있는 Schneider's 배지 (Gibco, USA)로 1시간 동안 상온에서 교반 시키고, 250× $g$ 에서 5 분 동안 원심 분리하여 효소 및 장 조직을 제거한 후 수거된 장세포는 $1 \times \mathrm{PBS}$ 로 2 회 세척하였다. 세척된 장세포는 $1 \times$ penicillin-streptomycin (Gibco USA), 1×Fungizone (Gibco USA), $1 \times$ gentamycin (Gibco, USA) 및 $10 \%$ FBS를 첨가한 Schneider's 배지를 이용하여 매일 배지를 교체하며 배양하였 다. 장세포 일차 배양의 전 과정을 Fig. 1에 도식화하였다.

세포 증식 측정(cell proliferation assay)

장 일차배양 세포의 생장률을 확인하기 위해 MTS assay를 수행하였다. CellTiter 96® AQueous One Solution Cell

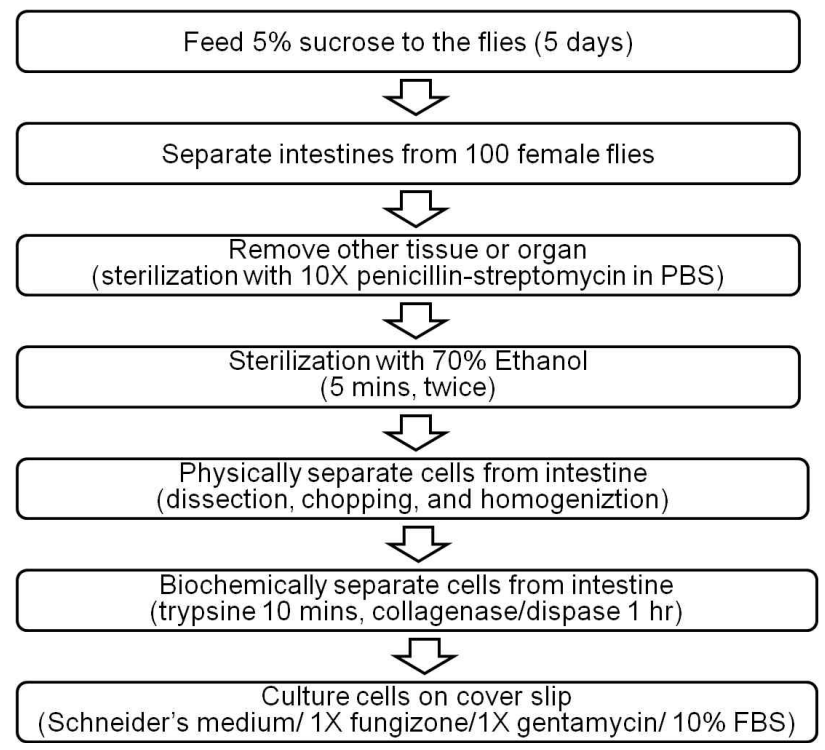

Fig. 1. Flow chart summarizing primary culture experiment of Drosophila intestinal cells.
Proliferation Assay (Promega, USA)를 이용하여 일차배양한 장 세포 $\left(5 \times 10^{5}\right.$ cells $\left./ \mathrm{ml}\right)$ 를 96-well plate에 분주하고 각 well에 CellTiter 96® AQueous One Solution Reagent $10 \mu 1$ 를 첨가한 후 4 시간 동안 반응 시킨 다음 $450 \mathrm{~nm}$ 에서 흡광도를 측정하였 다. 일차세포 배양 후 세포의 형태 및 오염여부 확인을 위해 광학현미경 (Carl Zeiss, Germany)을 40배 배율로 1일 간격으 로 14 일 동안 관찰하고 세포 사진을 촬영하였다.

\section{면역염색법(Immuostaining)}

일차 배양 장세포에 포함된 세포 종류 확인을 위해 immunostaining을 수행하였다. Immunostaining을 위하여 일차 항체로는 1:100 delta (Hybridoma Bank, USA)와 1:1,500 prospero (Hybridoma Bank, USA)를 사용하였다. 우선 일차배양 한 장세포를 $1 \times \mathrm{PBS}$ 로 2 회 세척하고 $1.5 \mathrm{ml}$ tube로 옮긴 후 $250 \times g$ 에서 5 분간 원심분리하여 세포를 회수하였다. PBS를 제거하고 상온에서 15 분 동안 $4 \%$ Formaldehyde/ $1 \times \mathrm{PBS}$ (Sigma, USA)를 이용하여 세포를 고정하고 상온에서 $0.1 \%$ Triton X-100/PBS로 2회 세척한 후 5\% horse serum $/ 1 \%$ $\mathrm{BSA} / 1 \times \mathrm{PBS}$ 로 1 시간 30 분 동안 상온에서 blocking 하였다. 그 다음으로 세포는 일차항체와 반응시켰다. Delta는 상온에서, prospero는 $4^{\circ} \mathrm{C}$ 에서 하루 동안 반응시키고, $1 \times \mathrm{PBS}$ 로 20 분간 4 회 세척한 후 Allexa flour secondary antibody (Molecular Probes, USA)를 이용하여 세포를 형광염색 후 PBS로 20분간 4 회 세척하였다. $250 \times g$ 에서 5 분간 원심분리하여 회수한 세포 를 슬라이드글라스에 미리 점적한 Vectashield mounting solution (VECTOR, USA)에 mounting하여 세포를 DAPI (4',6-diamidino-2-phenylindole)로 염색한 다음 형광현미경 (Carl Zeiss DE/Axio Imager A1, Germany)으로 형광염색 여 부를 관찰하였다.

\section{결과 및 고찰}

염증성 장질환 원인 구명 및 치료제 개발 연구의 일환으로 초파리를 모델곤충으로 이용한 선행 연구 결과를 통해 초파리 성충 중장(midgut)에 존재하는 장줄기 세포(intestinal stem cell, ISC)가 장 조직의 유지와 장 손상에 의해 소실된 세포를 원래 가지고 있는 세포수만큼 보충하여서 장을 구성하는 세포 수의 항상성 유지에 매우 중요한 역할을 수행함을 확인하였다 [15]. 그리고 ISC 분열 및 분화 촉진을 통해 장 손상 복구에 중요한 역할을 수행할 것으로 추정되는 후보 유전자를 선발하 고 그 기능을 분석하고자 하였으나, 초파리 생체를 이용한 실 험의 경우 후보 유전자로부터 발현한 재조합 단백질의 기능 검증을 위해 초파리에 경구투여를 할 경우 다양한 protease 등의 작용에 의해 목적지인 $\mathrm{ISC}$ 가 존재하는 중장에까지 고유 의 구조와 기능을 가지고 도달하기 힘들다는 단점을 가지고 있었다. 따라서 우리는 본 연구에서 ISC 분열 및 분화 촉진 

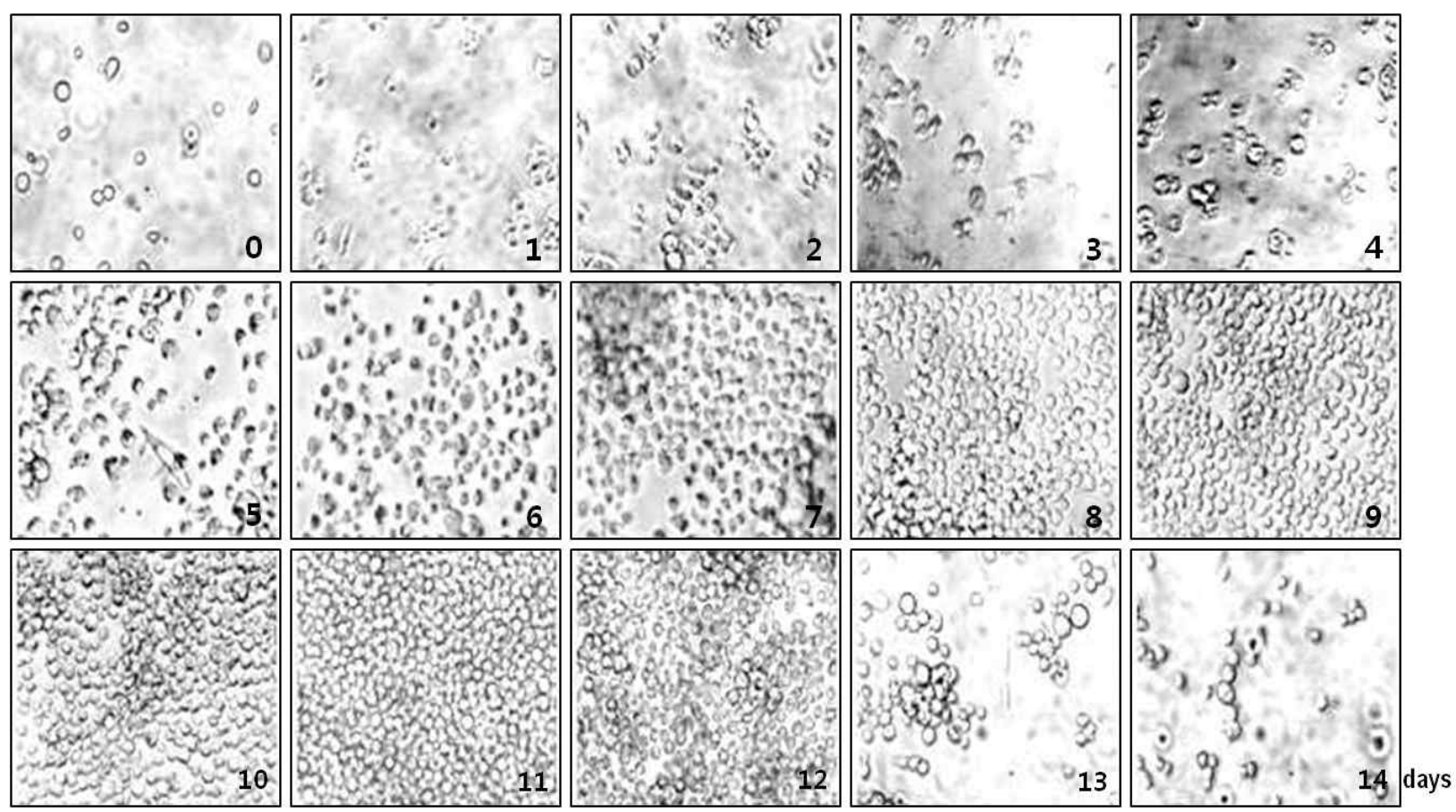

Fig. 2. Primary cultured Drosophila melanogaster gut cell monolayer. After seeding of gut cells, the cell images were photographed under a phased-contrast microscope at internals of 24 hours $(\times 40)$. Detailed processing steps are described in the Material \& Method

기능을 가질 것으로 추정되는 후보 유전자의 효율적인 기능 분석뿐만 아니라 나아가 다양한 장에서 발생하는 질환 연구에 유용하게 이용될 장세포 일차배양을 초파리를 이용하여 시도 하였다.

곤충의 중장은 사람의 위에 해당하므로 많은 다양한 장내 미생물이 존재할 뿐만 아니라 초파리 사료에도 효모 등 다양 한 미생물이 포함되어져 있으므로 가능한 장 내 미생물 수를 최소화하기 위해 장 해부에 앞서 초파리의 먹이로 5 일 동안 $5 \%$ 의 sucrose만을 급여하였다. 그 후 초파리 성충을 해부하여 장을 분리하고 염소 소독제인 $1.5 \%$ chlorine bleach로 5 분간 1 회 소독한 후 세포를 배양한 결과 배양 후 5 일째부터 세포의 배양액이 미생물로 오염되었음을 현미경 검경을 통해 확인할 수 있었다. 그리고 장을 $70 \%$ 에탄올과 $1.5 \%$ chlorine bleach를 혼합해서 5 분간 1 회 소독한 경우에는 미생물의 오염은 없었으 나 세포가 손상되어서 핵에 염색되는 DAPI (4',6-diamidino-2-phenylindole) 염색결과 대부분의 세포가 염색되지 않음을 확인할 수 있었고, MTS assay에 의해서도 대부분의 세포가 사멸되었음을 확인할 수 있었다. 다음으로 $1.5 \%$ chlorine bleach는 사용하지 않고 70\% 에탄올로만 5분간 2회 소독 을 실시해 보았다. 그 결과 세포가 미생물에 오염되지 않아 일차배양 후 14 일째까지 미생물에 오염되지 않고 세포가 잘 생존함을 현미경 검경을 통해 확인할 수 있었다(Fig. 2). 그리 고 cell proliferation 분석을 통해 최대성장시기, 세포생존기간 및 세포생장곡선 등을 확인하기 위해 MTS assay를 수행한

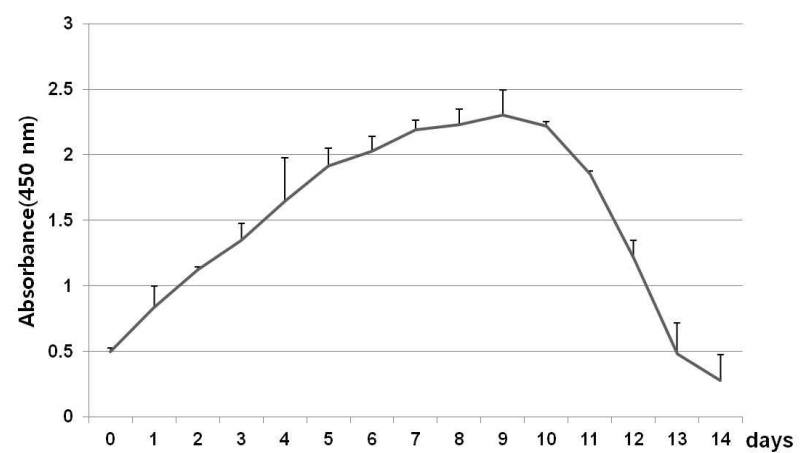

Fig. 3. Cell number on absorbance at $490 \mathrm{~nm}$ measured using the CellTiter 96® AQueous One Solution Assay (Promega, USA). Primary cultured Drosophila melanogaster gut cells $\left(5 \times 10^{5}\right.$ cells $\left./ \mathrm{ml}\right)$ were cultured on the 96-well plate. The medium was allowed to equilibrate for 1 hour, then $10 \mu \mathrm{l} /$ well of CellTiter $96 \AA$ AQueous One Solution Reagent was added. After 4 hour at $25^{\circ} \mathrm{C}$, the absorbance at $450 \mathrm{~nm}$ was recorded using an ELISA plate reader. The graph shows the averages of the quantified data from 3 independent experiments.

결과 세포는 일차배양 시작 후 서서히 증식하여 8일째 최대로 분열됨을 확인하였고, 그 이후 서서히 세포수가 감소하였으 며, 최대 14일까지 유지됨을 확인할 수 있었다(Fig. 3).

본 연구에서 구축한 일차배양 장세포가 살아있는 초파리 의 장과 동일한 세포들로 구성되어 있어서 초파리의 장을 대 

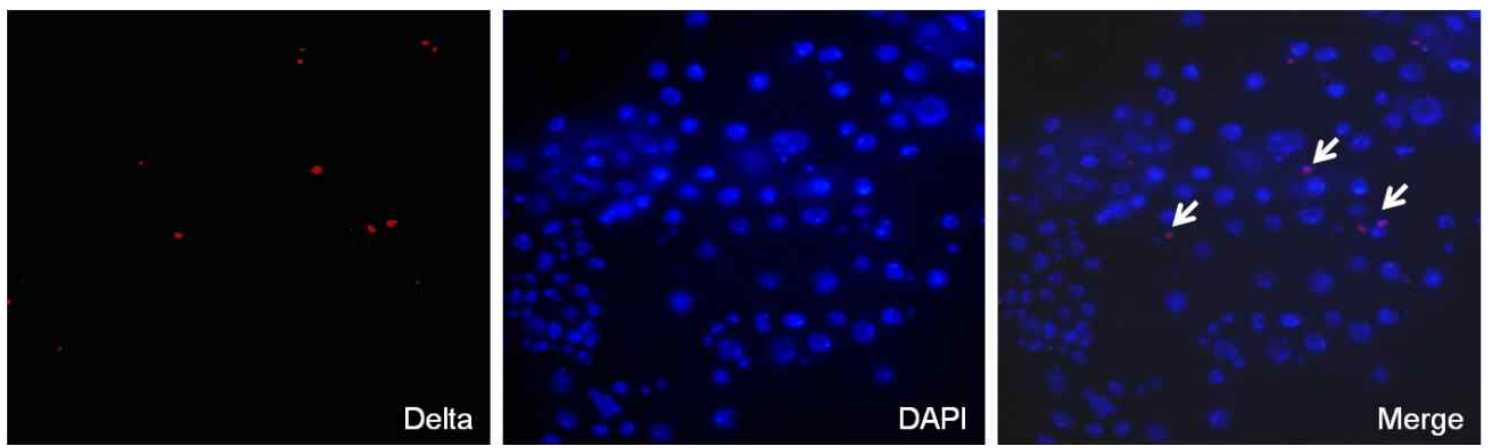

$(\times 40)$

Fig. 4. Immunostaining with delta (red) and nuclear staining DAPI (blue). The cells designated by the white arrows were both delta and DAPI positive cells. Purple in merged images indicates colocalization between red (delta) and blue (DAPI) colors $(\times 40)$.
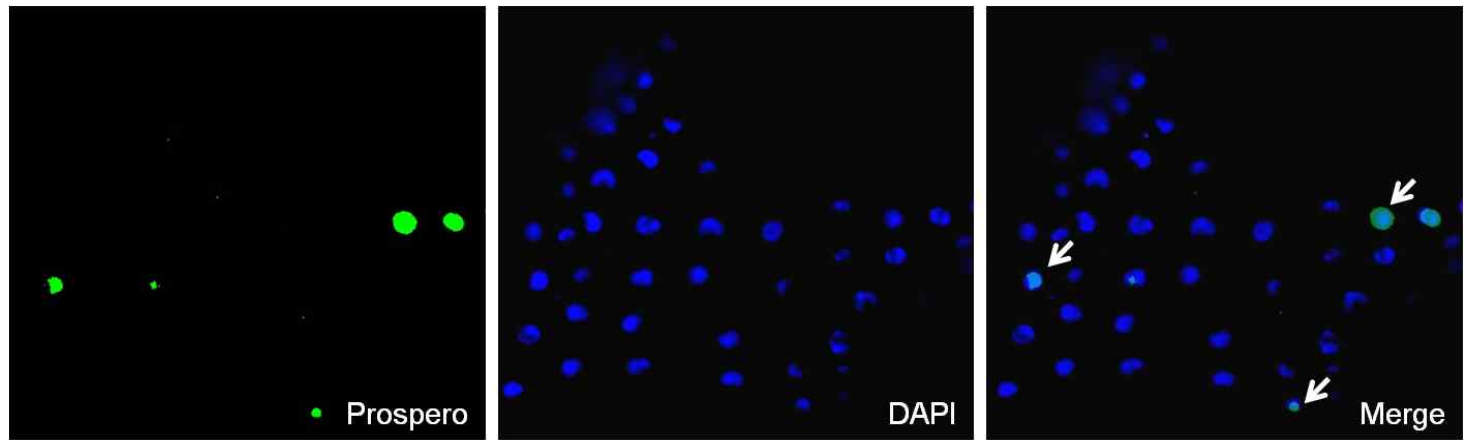

$(\times 40)$

Fig. 5. Immunostaining with prospero (green) and nuclear staining DAPI (blue). The cells designated by the white arrows were both prosporo and DAPI positive cells. Skyblue in merged images indicates colocalization between prospero (green) and blue (DAPI) colors $(\times 40)$.

상으로 하는 여러가지 연구에 적합한지를 확인하기 위해 초 파리 장을 구성하는 세포인 enterocyte, enteroblast, enteroendocrine cell 및 ISC 존재 여부를 확인하였다. 전체적인 세포의 이미지는 DAPI staining에 의해 확인하였고, ISC 및 enteroendocrine cell의 마커로 각각 delta와 prospero를 사 용하여 immunostaining을 실시하였다(Fig. 4, 5). 그 결과 DAPI와 delta staining에 의해 염색되는 장을 구성하는 세포 중 크기가 가장 적은 성체 장줄기세포(ISC)를 확인할 수 있 었다(Fig. 4). Delta에 의해 염색되는 세포수는 DAPI에 의해 염색되는 세포의 약 $10 \%$ 를 차지하였으므로 초파리의 생체에 서와 마찬가지로 ISC는 전체 장세포 중 각각 약 $10 \%$ 를 차지 함을 추정할 수 있었다[3]. 따라서 본 연구에서 구축한 일차 배양세포는 생체 장세포 환경과 유사하므로 ISC 분열 및 분 화 촉진 기능을 가질 것으로 추정되는 후보 유전자의 효율적 인 기능 분석을 통한 ISC 분열 및 분화조절 연구에 유용할 것으로 추정되었다.

한편, prospero 염색에 의해 prospero 및 DAPI에 동시 염색 되는 장 내분비세포(enteroendocrine cell)의 존재를 확인하였
다(Fig. 5). DAPI는 청색의 형광 염료로서 DNA의 AT cluster 가 있는 minor groove에 결합하는 형광물질이어서 모든 세포 에 염색되므로[10], DAPI에 의해 염색되면서 prospero나 delta에 의해 염색되지 않은 세포 중 크기가 큰 세포는 enterocyte, 크기가 작은 세포는 enteroblast로 추정되었다. 따라서, 본 연 구에서 구축한 일차배양 장세포에는 생체와 동일하게 초파리 장에 존재하는 모든 세포가 존재하므로 생체 내의 장과 유사 할 것으로 추정되므로 본 연구에서 구축된 세포는 염증성 장 질환과 관련된 장줄기세포 조절 연구뿐만 아니라 장에서 발병 하는 다양한 질병 기작 연구에 보다 용이하게 이용될 것으로 기대된다.

\section{감사의 글}

본 연구는 농림수산식품부에서 지원하는 2011년도 생명산 업기술개발사업(311006-3) 의 연구수행으로 인한 결과물임을 밝힙니다. 


\section{References}

1. Amcheslavsky, A., Jiang, J. and Ip, Y. T. 2009. Tissue damage-induced intestinal stem cell division in Drosophila. Cell Stem Cell 4, 49-61.

2. Apidianakis, Y. and Rahme, L. G. 2011. Drosophila melanogaster as a model for human intestinal infection and pathology. Dis. Model Mech 4, 21-30.

3. Benjamin, O. and Allan, S. 2005. The adult Drosophila posterior midgut is maintained by pluripotent stem cells. Nature 439, 470-474.

4. Cha, S. J. and Han, S. S. 1999. Establishment of a novel cell line from Plutella xylostella fat bodies. Korean J. Entomol. 29, 121-126.

5. Davis, T. R., Trotter, K. M., Granados, R. R. and Wood, H. A. 1992. Baculovirus expression of alkaline phosphatase as a reporter gene for evaluation of production, glycosylation, and secretion. Biotechnology 10, 1148-1150.

6. Evans, G. S., Flint, N. and Potten, C. S. 1994. Primary cultures for studies of cell regulation and physiology in intestinal epithelium. Annu. Rev. Physiol. 56, 399-417.

7. Grace, T. D. 1962. Establishment of four strains of cells from insect tissues grown in vitro. Nature 195, 788-789.

8. Granados, R. R., Guoxun, L., Derksen, A. C. G. and McKenna, K. A. 1994. A new insect cell line from Trichoplusia ni (BTI-Tn-5B1-4) susceptible to Trichoplusia ni single enveloped nuclear polyhedrosis virus. J. Invertebr. Pathol. 64, 260-266.

9. Juan, J. G., Guoxun, L., Ping, W., Jiang, Z. and Robert, R. G. 2001. Primary and continuous midgut cell cultures from Pseudaletia unipuncta (Lepidoptera: Noctuidae). In Vitro Cell Dev. Biol. Anim 37, 353-359.

10. Kapuscinski, J. 1995. DAPI: a DNA-specific fluorescent probe. Biotech. Histochem 70, 220-233.

11. Lanzoni, G., Roda, G., Belluzzi, A., Roda, E. and Bagnara, G. P. 2008. Inflammatory bowel disease: Moving toward a stem cell-based therapy. World J. Gastroenterol. 14, 4616-4626.

12. Lüer, K. and Technau, G. M. 1992. Primary culture of single ectodermal precursors of Drosophila reveals a dorsoventral prepattern of intrinsic neurogenic and epidermogenic capabilities at the early gastrula stage. Development 116, 377-385.

13. Noguchi, T. and Miller, K. G. 2003. A role for actin dynamics in individualization during spermatogenesis in Drosophila melanogaster. Development 130, 1805-1816.

14. O'Reilly, D. R., Miller, L. K. and Luckow, V. A. 1992. Baculovirus Expression Vectors: A Laboratory Manual (New York, N. Y.: Freeman, W. H. and Company).
15. Palli, S. R., Caputo, G. F., Brownwright, A. J. and Sofi, S. S. 1997. Studies on apoptosis in a continuous midgut cell line, CF-203, of the spruce budworm, Choristoneura fumiferana (Lepidoptera: Tortricidae). In: Maramorosch. K., and Mitsuhashi, J. (eds.), pp. 43-51, Invertebrate cell culture Novel directions and biotechnology applications. Science, Enfield

16. Pan, C., Kumar, C., Bohl, S., Klingmueller, U. and Mann, M. 2009. Comparative proteomic phenotyping of cell lines and primary cells to assess preservation of cell type-specific functions. Mol. Cell Proteomics 8, 443-450.

17. Raziel, S. H., Silvia, C., Marcia, L., and Guy, S. 2009. Primary culture of insect midgut cells. In Vitro Cell Dev. Biol. Anim 45, 106-110.

18. Ren, F., Wang, B., Yue, T., Yun, E. Y., Ip, Y. T. and Jiang, J. 2010. Hippo signaling regulates Drosophila intestine stem cell proliferation through multiple pathways. Proc. Natl. Acad Sci. USA 107, 21064-21069.

19. Roda, G., Sartini, A., Zambon, E., Calafiore, A., Marocchi, M., Caponi, A., Belluzzi, A. and Roda, E. 2010. Intestinal epithelial cells in inflammatory bowel diseases. World J. Gastroenterol. 16, 4264-4271.

20. Sicaeros, B., Campusano, J. M. and O’Dowd, D. K. 2007. Primary neuronal cultures from the brains of late stage Drosophila pupae. J. Vis. Exp. 4, 200.

21. Siegmund, B. and Zeitz, M. 2011. Innate and adaptive immunity in inflammatory bowel disease. World J. Gastroenterol. 17, 3178-3183

22. Soin, T., Swevers, L., Mosallanejad, H., Efrose, R., Labropoulou, V., Iatrou, K. and Smagghe, G. 2008. Juvenile hormone analogs do not affect directly the activity of the ecdysteroid receptor complex in insect culture cell lines. $J$. Insect Physiol. 54, 429-438.

23. Vaughn, J. L., Goodwin, R. H., Tompkins, G. J. and McCawley, P. 1977. The Establishment of two cell lines from the insect Spodoptera frugiperda (Lepidoptera: Noctuidae). In Vitro 13, 213-217.

24. Wickham, T. J. and Nemerow, G. R. 1993. Optimization of growth methods and recombinant protein production in BTI Tn-5B1-4 insect cells using the baculovirus expression vector. Biotechnol. Prog. 9, 25-30.

25. Wickham, T. J., Davis, T., Granados, R. R., Shuler, M. L. and Wood, H. A. 1992. Screening of insect cell lines for the production of recombinant proteins and infectious virus in the baculovirus expression system. Biotechnol. Prog. 8, 391-396.

26. Wirtz, S. and. Neurath, M. F. 2007. Mouse models of inflammatory bowel disease. Adv. Drug Deliv. Rev. 59, 1073-1083. 


\section{초록 : 장줄기세포 조절 연구를 위한 초파리 장세포의 일차배양}

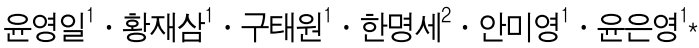

('농촌진흥청 국립농업과학원 농업생물부, ${ }^{2}$ 경북대학교 바이오섬유소재학과)

초파리는 발생과 질병연구를 위한 모델 곤충으로 널리 이용되어 왔다. 본 연구에서도 초파리를 모델곤충으로 한 장질환 연구의 일환으로 다양한 병원균 감염 및 장질환 유발시 어떻게 장줄기세포가 작용하는지를 이해하기 위해 초파리 장세포의 일차배양 방법을 확립하였다. 초파리 성충으로부터 장을 해부하고 다양한 효소를 처리하 여 장세포를 분리한 후 배양하였다. 배양세포의 생존여부는 현미경 검경 및 MTS assay에 의해 확인한 결과 배 양 후 9 일째 최대 증식되었고 14 일까지 생존함을 확인할 수 있었다. 또한 장줄기세포 및 장내분비세포의 존재도 immunostaining에 의해 확인하였다. 따라서 본 연구에서 구축된 초파리 일차배양 장세포는 다양한 유전자에 의 한 장줄기 세포 조절연구뿐만 아니라 장에서 발생하는 다양한 질병을 연구하는 도구로 매우 유용할 것으로 추 측된다. 